\title{
Effects of temperature and food availability on growth, survival, and RNA-DNA ratio of larval sand lance (Ammodytes americanus)*
}

\author{
L. J. Buckley, S. I. Turner, T. A. Halavik, A. S. Smigielski, S. M. Drew and \\ G. C. Laurence
}

National Oceanic and Atmospheric Administration, National Marine Fisheries Service, Northeast Fisheries Center, Narragansett Laboratory, Narragansett, Rhode Island 02882, USA

\begin{abstract}
Beginning 2, 19, and $30 \mathrm{~d}$ after hatching, larvae of sand lance Ammodytes americanus were reared for 1 or $2 \mathrm{wk}$ between 2 and $9^{\circ} \mathrm{C}$ in the absence of food and at nominal feeding levels of 200 to 1,000 rotifers $\mathrm{I}^{-1}\left(0.16\right.$ to $\left.0.80 \mathrm{cal} \mathrm{l}^{-1}\right)$. Mortality of all age groups was unaffected by temperature. The mean daily instantaneous mortality coefficient of newly hatched larvae was 0.01 to Day 16 and was unaffected by feeding level. Mean daily instantaneous mortality coefficients of older larvae ranged from 0.2 to 0.02 and decreased with increasing feeding level. Growth rate and RNA-DNA ratio increased with increasing feeding level. A direct linear relation observed between RNA-DNA ratio and growth rate was improved by adding temperature as a second independent variable. The relation between RNA-DNA ratio, temperature, and larval growth rate was insensitive to either larval size (protein content) or age.
\end{abstract}

\section{INTRODUCTION}

Sand lance, sprat, and Norway pout have been described as small, fast-growing, opportunistic plankton-feeding fish. Their populations have exploded in the 1970's in the North Sea and the Northwest Atlantic Ocean. It has been suggested that in these areas they are replacing heavily fished and larger tertiary predators, including herring and mackerel (Ursin, 1977; Andersen and Ursin, 1978; Sherman et al., 1981). Despite these observations and the importance of sand lance in the North Atlantic as a major biomass component and as an abundant food resource for larger fish and marine mammals, little is known of their early life history. Laboratory studies were initiated as part of the National Marine Fisheries Service (MARMAP program (Sherman, 1980) to determine important early life history parameters of sand lance pertinent to studies of population dynamics and marine ecosystems.

Spawning, embryo development and growth of Ammodytes americanus at temperatures between 2 and $10^{\circ} \mathrm{C}$ have been described elsewhere (Smigielski et al., 1983). We report here results of 3 experiments in

\footnotetext{
- MARMAP Contribution MED/NEFC 83-08
}

which different-age sand lance were reared in the absence of food and at plankton densities between 200 and 1,000 plankters $\mathrm{l}^{-1}$ for a period of 1 to $2 \mathrm{wk}$. These experiments were designed to study growth, survival, and condition of sand lance at low plankton densities. This study also provides the first opportunity to examine the interactive effects of temperature and food availability on larval RNA-DNA ratio and on the relationship between RNA-DNA ratio and larval growth rate.

\section{METHODS}

Details on the laboratory spawning and rearing of Ammodytes americanus have been described (Smigielski et al., 1983). Adults were spawned at temperatures between 7.0 and $4.5^{\circ} \mathrm{C}$. Embryos were acclimated to $2,4,7$ and $10^{\circ} \mathrm{C}$. Stock tanks of larval sand lance were fed ad libitum a mixture of rotifers, brine shrimp and wild plankton.

Three separate experiments were conducted with different-age larvae. At each experimental temperature separate groups of larvae were starved or fed a diet of rotifers Brachionus plicatilis at nominal densities of 200,500 , and 1,000 plankters $\mathrm{l}^{-1}$. Using 
Table 1. Monitored rotifer concentrations for the 3 nominal plankton densities. Values are the mean \pm 1 standard deviation of the daily counts made just prior to adjustment to the nominal levels

\begin{tabular}{|c|c|c|c|c|}
\hline \multirow{3}{*}{$\begin{array}{c}\text { Experi- } \\
\text { ment } \\
\text { no. }\end{array}$} & \multirow{3}{*}{$\begin{array}{c}\text { Tempera- } \\
\text { ture } \\
\left({ }^{\circ} \mathrm{C}\right)\end{array}$} & \multicolumn{3}{|c|}{$\begin{array}{l}\text { Nominal rotifer concentration } \\
\text { (rotifers } \mathrm{ml}^{-1} \text { ) }\end{array}$} \\
\hline & & 0.2 & 0.5 & 1.0 \\
\hline & & \multicolumn{3}{|c|}{$\begin{array}{l}\text { Monitored rotifer concentration } \\
\text { (rotifers } \mathrm{ml}^{-1} \text { ) }\end{array}$} \\
\hline \multirow[t]{3}{*}{ I } & 5 & $0.12 \pm 0.14$ & $0.22 \pm 0.24$ & $0.56 \pm 0.42$ \\
\hline & 7 & $0.14 \pm 0.13$ & $0.26 \pm 0.26$ & $0.88 \pm 0.70$ \\
\hline & 9 & $0.12 \pm 0.16$ & $0.34 \pm 0.25$ & $0.75 \pm 0.74$ \\
\hline \multirow[t]{3}{*}{ II } & 5 & $0.08 \pm 0.09$ & $0.23 \pm 0.22$ & $0.48 \pm 0.38$ \\
\hline & 7 & $0.04 \pm 0.06$ & $0.05 \pm 0.07$ & $0.40 \pm 0.30$ \\
\hline & 9 & $0.03 \pm 0.11$ & $0.05 \pm 0.08$ & $0.49 \pm 0.32$ \\
\hline \multirow[t]{3}{*}{ III } & 5 & $0.07 \pm 0.11$ & $0.23 \pm 0.39$ & $0.39 \pm 0.61$ \\
\hline & 3 & $0.02 \pm 0.23$ & $0.23 \pm 0.20$ & $0.56 \pm 0.41$ \\
\hline & 9 & $0.13 \pm 0.14$ & $0.33 \pm 0.19$ & $0.66 \pm 0.31$ \\
\hline
\end{tabular}

$8 \times 10^{-4}$ as the caloric content of an individual rotifer (Theilacker and McMaster, 1971), these feeding levels correspond to $0.16,0.40$ and $0.80 \mathrm{cal} \mathrm{l}^{-1}$. Rotifer concentrations were established by maintaining a constant volume of sea water in each aquarium (38 l) and adding the desired number of rotifers. Rotifer concentration was adjusted daily based on the mean count of duplicate $5 \mathrm{ml}$ samples from each aquarium (Table 1). The actual mean plankton densities experienced by the larvae fell somewhere between the nominal and measured levels. Rotifers were cultured in 191 glass carboys and fed Tetraselmis soucii (see Theilacker and McMaster, 1971). Large numbers of $T$. soucii cells were transferred incidentally to the aquaria with the rotifers.

\section{Experiment I}

Two days after hatching at $7^{\circ} \mathrm{C}, 300$ sand lance larvae were transferred to each of twelve $38 \mathrm{l}$ aquaria maintained at $7^{\circ} \mathrm{C}$. The temperature of 4 aquaria was gradually lowered to $5^{\circ} \mathrm{C}$ at the rate of $1 \mathrm{C}^{\circ}$ in $6 \mathrm{~h}$ while the temperature of 4 other aquaria was raised to $9{ }^{\circ} \mathrm{C}$. Thereafter, the temperature of each group of 4 aquaria was maintained at 5,7 and $9^{\circ} \mathrm{C}$ for the $2 \mathrm{wk}$ duration of the experiment.

\section{Experiment II}

Thirty days after hatching, 200 larvae from a $7^{\circ} \mathrm{C}$ stock tank were transferred to each of twelve 38 l aquaria. The temperature regime was adjusted and maintained as above for the $2 \mathrm{wk}$ duration of the experiment.

\section{Experiment III}

Nineteen days after hatching, 100 larvae from a $2{ }^{\circ} \mathrm{C}$ stock tank were transferred to each of twelve 381 experimental aquaria maintained at $2{ }^{\circ} \mathrm{C}$. The water temperature of 4 aquaria was gradually raised over $12 \mathrm{~h}$ to $4{ }^{\circ} \mathrm{C}$. The temperature of a second group of 4 aquaria was raised over $24 \mathrm{~h}$ to $6{ }^{\circ} \mathrm{C}$. Thereafter, the temperatures of each group of 4 aquaria were maintained at 2,4 and $6{ }^{\circ} \mathrm{C}$ for the 1 wk duration of the experiment.

Triplicate samples of between 10 and 30 larvae each were taken for biochemical analysis from the stock tanks just prior to the start of each experiment, and from the experimental tanks $1 \mathrm{wk}$ after the start of each experiment and at termination. Ten larvae were also removed at these times for measurement of standard length and dry weight. Samples were analyzed for RNA, DNA, and protein content as described by Buckley (1979). The instantaneous protein growth rate $\left(G_{p 1}\right)$ was calculated using the formula:

$$
G_{p i}=\frac{\ln W t_{2}-\ln W t_{1}}{t_{2}-t_{1}} \times 100
$$

where $\mathrm{W}=$ protein content in $\mathrm{mg} \mathrm{larva}^{-1} ; \mathrm{t}=$ age in days. Since the number of larvae stocked in a tank (St), the number removed for sampling, and the number recovered live at the end of the experiment $\left(\mathrm{St}^{1}\right)$ were known it was possible to calculate average daily instantaneous mortality coefficients $(Z)$ using the formula:

$$
\mathrm{Z}=\frac{\ln \mathrm{St}-\ln \mathrm{St} \mathrm{t}^{1}}{\mathrm{~d}}
$$

where $d=$ duration of the experiment in days. For Experiments I and II unbiased estimates of mortality ( $($ ), corrected for potential survivors that had been removed in sampling, were obtained using the equations:

$$
\begin{aligned}
& \hat{S} t^{1}=S t^{1}+N e^{-7 z} \\
& \hat{z}=\frac{\ln S t-\ln \hat{S} t^{1}}{d}
\end{aligned}
$$

where $\mathrm{N}=$ number of individuals removed for the week-one sample; $7=$ days in 1 wk (Laurence, 1974). $\hat{Z}$ for each experiment was arrived at by first calculating an initial $Z$ value using Equation (2) assuming no survivors from samples taken then iteratively correcting $\mathrm{St}^{1}$ in Equation (4) using Equation (3).

\section{RESULTS}

In the first experiment with $2 \mathrm{~d}$ old larvae the mean daily instantaneous mortality coefficient ( $($ ) for the 2 
wk duration of the experiment for all temperatures and plankton densities was $0.014 \pm 0.008$ and did not appear to be affected by either temperature or plankton density (2-way analysis of variance; $\mathrm{P}>0.05$ ). Because of the ample supply of endogenous energy reserves in newly hatched sand lance larvae, the $2 \mathrm{wk}$ duration of Experiment I was not long enough to estimate mortality rates at the various feeding levels. Mortality for the 2 wk duration of Experiment II with $30 \mathrm{~d}$ old larvae was strongly influenced by plankton density but not temperature (Table 2). Plankton densities as low as 200 plankters $\mathrm{l}^{-1}\left(0.16 \mathrm{cal} \mathrm{l}^{-1}\right)$ resulted in reduced mortalities compared to unfed groups at all 3 temperatures. The mean daily instantaneous mortality coefficient for Experiment III was $0.027 \pm 0.028$. For the $1 \mathrm{wk}$ duration of Experiment III $\mathrm{Z}$ did not appear to be affected by plankton density or temperature, demonstrating that sand lance larvae can readily survive one week of starvation and that the interval is too short to obtain estimates of $\mathrm{Z}$ at the various feeding levels.
RNA-DNA ratios of larvae reared under the various combinations of temperature and plankton density ranged from 0.98 to 4.0 . Instantaneous protein growth rates between $-6.7 \%$ and $12.2 \% \mathrm{~d}^{-1}$ were observed (Table 3). Two-way analysis of variance indicated that plankton density and, to a lesser extent, temperature and the interaction of the 2 variables had significant effects on the size, biochemical composition and RNADNA ratio of sand lance larvae (Table 4).

Data on the age, temperature, nominal plankton density, protein content, RNA-DNA ratio and growth rate at each sampling time for all three experiments were combined into one data matrix. Growth rate, protein content, age and plankton density, but not temperature, were correlated with RNA-DNA ratio (Table 5). Age, protein content, plankton density, and RNADNA ratio, but not temperature, were correlated with growth rate. A multiple linear regression model with age and plankton density as independent variables explained $76 \%$ of the variability in larval RNA-DNA ratio (Table 6). Adding temperature as a third indepen-

Table 2. Daily instantaneous mortality coefficient $(\hat{Z})$ for the 2 wk duration of Experiment II

\begin{tabular}{ccccc|}
\hline $\begin{array}{c}\text { Temperature } \\
\left({ }^{\circ} \mathrm{C}\right)\end{array}$ & 0 & $\begin{array}{c}\text { Nominal rotifer concentration (rotifers m }{ }^{-1} \text { ) } \\
0.2\end{array}$ & 0.5 & 1.0 \\
\hline 5 & 0.201 & 0.069 & 0.033 & 0.009 \\
7 & 0.203 & 0.056 & 0.016 & 0.035 \\
9 & 0.204 & 0.073 & 0.035 & 0.018 \\
$\bar{x} \pm \mathrm{s}$ & $0.203 \pm 0.002$ & $0.066 \pm 0.009$ & $0.028 \pm 0.010$ & $0.021 \pm 0.013$ \\
\hline
\end{tabular}

Table 3. RNA-DNA ratio and instantaneous protein growth rate $\left(G_{p i}\right)$ of sand lance larvae at various combinations of temperature and rotifer concentrations

\begin{tabular}{|c|c|c|c|c|c|c|c|c|c|c|}
\hline \multirow{3}{*}{$\begin{array}{l}\text { Experi- } \\
\text { ment no. }\end{array}$} & \multirow{3}{*}{$\begin{array}{c}\mathrm{T} \\
\left({ }^{\circ} \mathrm{C}\right)\end{array}$} & \multirow{3}{*}{$\begin{array}{l}\text { Time } \\
\text { (d) }\end{array}$} & \multicolumn{8}{|c|}{ Nominal rotifer concentration (rotifers $\mathrm{ml}^{-1}$ ) } \\
\hline & & & \multicolumn{2}{|c|}{0} & \multicolumn{2}{|c|}{0.2} & \multicolumn{2}{|c|}{0.5} & \multicolumn{2}{|c|}{1.0} \\
\hline & & & RNA/DNA & $\mathrm{G}_{\mathrm{pi}}$ & RNA/DNA & $G_{\mathrm{pi}}$ & RNA/DNA & $\mathrm{G}_{\mathrm{pl}}$ & RNA/DNA & $\mathrm{G}_{\mathrm{pi}}$ \\
\hline \multirow[t]{6}{*}{ I } & 5 & 7 & 1.95 & -6.67 & 2.25 & -1.95 & 2.51 & -2.68 & 2.43 & -1.71 \\
\hline & & 14 & 1.54 & 1.13 & 1.92 & -1.40 & 2.50 & 2.23 & 2.59 & 3.34 \\
\hline & 7 & 7 & 1.82 & -3.88 & 2.05 & -1.61 & 2.64 & -0.77 & 2.62 & 0.67 \\
\hline & & 14 & 1.23 & -4.74 & 2.27 & 1.15 & 2.66 & 4.43 & 3.82 & 12.16 \\
\hline & 9 & 7 & 1.57 & -4.94 & 2.08 & -2.65 & 1.99 & -4.90 & 2.87 & 2.98 \\
\hline & & 14 & 0.98 & -5.92 & 2.04 & 3.90 & 2.60 & 9.63 & 3.20 & 7.74 \\
\hline \multirow[t]{6}{*}{ II } & 5 & 7 & 2.95 & 0.53 & 3.20 & 1.23 & 3.76 & 3.95 & 3.49 & 1.15 \\
\hline & & 14 & - & - & 3.12 & 1.65 & 3.72 & 2.53 & 3.74 & 4.05 \\
\hline & 7 & 7 & 2.28 & 0.92 & 2.71 & -3.70 & 3.30 & 4.21 & 3.67 & 4.11 \\
\hline & & 14 & - & - & 2.96 & 5.21 & 3.46 & 3.72 & 3.59 & 4.14 \\
\hline & 9 & 7 & 2.23 & -0.92 & 2.78 & 0.63 & 3.28 & 4.90 & 3.30 & 4.69 \\
\hline & & 14 & - & - & 2.56 & 3.50 & 3.98 & 2.14 & 3.63 & 5.68 \\
\hline \multirow[t]{3}{*}{ III } & 2 & 7 & 2.27 & -0.33 & 3.23 & 1.18 & 2.95 & -1.97 & 3.09 & 0.55 \\
\hline & 4 & 7 & 1.71 & -6.37 & 2.64 & 0.05 & 3.02 & 2.06 & 3.55 & 3.79 \\
\hline & 6 & 7 & 1.51 & -6.59 & 3.04 & 2.14 & 3.12 & 1.00 & 3.77 & 3.18 \\
\hline
\end{tabular}


Table 4. F values for the effect of temperature ( $T$ ) and rotifer concentration (p) on size and biochemical composition of sand lance larvae. Two-way analysis of variance. ( $P \leqslant 0.05, \cdots P \leqslant 0.01)$. Values for starved larvae were not included in the analyses. The data made up a $3 \times 3$ matrix. In the case of standard length and dry weight there were 10 replicates per cell; others had 3 replicates per cell

\begin{tabular}{|c|c|c|c|c|c|c|c|}
\hline \multirow{2}{*}{\multicolumn{2}{|c|}{$\begin{array}{c}\text { Experiment } \\
\text { no. }\end{array}$}} & \multicolumn{3}{|c|}{ Week 1} & \multicolumn{3}{|c|}{ Week 2} \\
\hline & & $\mathrm{T}$ & $\mathrm{p}$ & $\mathrm{Txp}$ & $\mathrm{T}$ & $p$ & $\operatorname{Txp}$ \\
\hline \multirow[t]{7}{*}{ I } & Standard length & 0.5 & 1.1 & 0.7 & 0.3 & $19.2^{*}$ & 1.8 \\
\hline & Dry weight & 1.2 & 3.4 & 0.8 & $6.9^{\cdots}$ & $11.5^{*}$ & 2.1 \\
\hline & Protein & 1.7 & 9.9 & $4.1^{*}$ & $5.0^{\circ}$ & $7.0^{\cdots}$ & 2.5 \\
\hline & RNA & 0.9 & $23.8^{*}$ & $9.4^{\cdots}$ & $7.5^{\cdots}$ & $15.4^{*}$ & 2.9 \\
\hline & DNA & 2.1 & $11.9^{*}$ & $4.0^{\circ}$ & $4.5^{\circ}$ & $5.5^{\circ}$ & 1.3 \\
\hline & RNA/DNA & 2.2 & $31.8 *$ & $13.4^{*}$ & $12.2^{*}$ & $46.1^{\cdots}$ & $4.0^{\circ}$ \\
\hline & $\mathrm{G}_{1}$ & 1.9 & $10.6^{\cdots}$ & $4.2^{\circ}$ & $23.2^{\cdots}$ & $30.5^{\cdots}$ & $5.3^{\cdots}$ \\
\hline \multirow[t]{7}{*}{ II } & Standard length & 1.0 & $3.4^{\circ}$ & $2.5^{\circ}$ & 2.2 & $10.0^{\cdots}$ & 1.8 \\
\hline & Dгу wejght & 0.9 & $4.5^{\circ}$ & 2.1 & $6.2^{\cdots}$ & $13.4^{\cdots}$ & 1.1 \\
\hline & Protein & 1.2 & $9.3^{\cdots}$ & 1.2 & $4.3^{\circ}$ & $14.5^{\cdots}$ & 2.0 \\
\hline & RNA & 0.2 & $9.7^{\cdots}$ & 1.9 & $8.0^{\cdots}$ & $43.9^{\cdots}$ & $3.3^{*}$ \\
\hline & DNA & 2.2 & 2.2 & 1.0 & $11.4^{\cdots}$ & $11.1^{\cdots}$ & 2.6 \\
\hline & RNA/DNA & $5.2^{\circ}$ & $16.0^{\circ}$ & 1.8 & 0.7 & $14.9^{\cdots}$ & 1.5 \\
\hline & $G_{i}$ & 1.2 & $10.6^{\cdots}$ & 1.4 & 1.2 & 3.1 & 1.3 \\
\hline \multirow[t]{7}{*}{ III } & Standard length & - & - & - & & & \\
\hline & Dry weight & $6.3^{\cdots}$ & 0.6 & 1.6 & & & \\
\hline & Protein & $5.0^{\circ}$ & $6.0^{\circ}$ & 2.3 & & & \\
\hline & RNA & $13.1^{\cdots}$ & $9.9^{\cdots}$ & $3.1^{\circ}$ & & & \\
\hline & DNA & $20.0^{\cdots}$ & 2.4 & 0.9 & & & \\
\hline & RNA/DNA & 2.1 & $9.0^{\circ}$ & $3.3^{\circ}$ & & & \\
\hline & $G_{i}$ & $4.5^{\circ}$ & $4.8^{\circ}$ & 1.8 & & & \\
\hline
\end{tabular}

Table 5. Correlations among age, protein content, temperature, plankton density (Pl ml $\left.{ }^{-1}\right), R^{\prime} A-D N A$ ratio and growth rate $\left(\mathrm{G}_{\mathrm{pi}}\right)$ of larval sand lance. Numbers are correlation coefficients (r), $N=57$

\begin{tabular}{|c|c|c|c|c|c|}
\hline & $T$ & $\mathrm{Pl} \mathrm{mI^{-1 }}$ & RNA/DNA & $G_{p i}$ & Age \\
\hline $\mathrm{T}\left({ }^{\circ} \mathrm{C}\right)$ & - & & & & \\
\hline$P I \mathrm{ml}^{-\mathrm{I}}$ & 0.04 & - & & & \\
\hline RNA/DNA & -0.08 & $0.67^{\circ}$ & - & & \\
\hline$G_{p !}\left(\% d^{-1}\right)$ & 0.14 & $0.62^{\bullet}$ & $0.74^{\circ}$ & - & \\
\hline Age (d) & -0.03 & 0.16 & $0.61^{\circ}$ & $0.37^{\circ}$ & - \\
\hline $\begin{array}{l}\text { Protein content } \\
\left.(\mu \mathrm{g} \mathrm{larva})^{-1}\right)\end{array}$ & $0.38^{\circ}$ & $0.44^{\circ}$ & $0.70^{\circ}$ & $0.64^{\circ}$ & $0.41^{\circ}$ \\
\hline$p \leqslant 0.01$ & & & & & \\
\hline
\end{tabular}

Table 6. Relations between age, temperature, RNA/DNA, and growth rate ( $G_{\text {pi }}$ ) in larval sand lance

\begin{tabular}{|c|c|c|c|c|c|c|c|}
\hline $\begin{array}{c}\text { Equation } \\
\text { no. }\end{array}$ & $\mathrm{x}_{1}$ & $\mathrm{x}_{2}$ & $\mathrm{x}_{3}$ & $\mathrm{Y}$ & & $N$ & $r^{2}$ \\
\hline 1 & $\mathrm{Pl} \mathrm{ml^{-1 }}$ & Age & - & RNA/DNA & $Y=1.20 X_{1}+0.03 X_{2}+1.40$ & 57 & $0.76^{\circ}$ \\
\hline 2 & Pl $\mathrm{ml}^{-1}$ & Age & $T$ & RNA/DNA & $Y=1.18 X_{1}+0.03 X_{2}^{2}-0.04 X_{3}+1.64$ & 57 & $0.76^{\circ}$ \\
\hline 3 & Pl $\mathrm{ml}^{-1}$ & Prot & - & RNA/DNA & $Y=0.89 X_{1}+0.01 X_{2}-1.67$ & 57 & $0.67^{*}$ \\
\hline 4 & RNA/DNA & - & - & $G_{\mathrm{pi}}$ & $Y=4.10 X_{1}-10.03$ & 57 & $0.55^{\circ}$ \\
\hline 5 & RNA/DNA & $\mathrm{T}^{\circ} \mathrm{C}$ & - & $\mathrm{G}_{\mathrm{pi}}$ & $Y=4.24 X_{1}+0.49 X_{2}-13.52$ & 57 & $0.61^{\circ}$ \\
\hline 6 & RNA/DNA & $\mathrm{T}^{\circ} \mathrm{C}$ & $\mathrm{Pl} \mathrm{\textrm {ml } ^ { - 1 }}$ & $G_{p 1}^{p 1}$ & $Y=3.55 X_{1}+0.45 X_{2}+1.97 X_{3}-12.31$ & 57 & $0.63^{\circ}$ \\
\hline 7 & RNA/DNA & $T^{\circ} \mathrm{C}$ & Age & $G_{p i}$ & $Y=4.83 X_{1}+0.50 X_{2}-0.06 X_{3}-13.83$ & 57 & $0.63^{\circ}$ \\
\hline 8 & RNA/DNA & $\mathrm{T}^{\circ} \mathrm{C}$ & Prot & $G_{p}$ & $Y=4.24 X_{1}+0.49 X_{2}-0.0001 X_{3}-13.53$ & 57 & $0.61^{*}$ \\
\hline 9 & Pl $\mathrm{ml}^{-1}$ & $\mathrm{~T}^{\circ} \mathrm{C}$ & - & $G_{p}$ & $Y=6.55 X_{1}+0.31 X_{2}-3.73$ & 57 & $0.40^{*}$ \\
\hline$\cdot P \leqslant 0.0$ & & & & & & & \\
\hline
\end{tabular}


dent variable did not further reduce the residual mean square. A direct linear relation was observed between RNA-DNA ratio and growth rate (Table 6). The addition of temperature as a second independent variable significantly reduced the residual mean square. Addition of either age, protein content, or plankton density as a third independent variable when RNA-DNA ratio and temperature were already in the regression equation removed very little of the unexplained variation in growth rate.

\section{DISCUSSION}

The direct linear relation between RNA-DNA ratio and growth rate of larval sand lance (Table 6, Equation 4 ) is similar to relations observed for larval cod Gadus morhua, (Buckley, 1979); winter flounder Pseudopleuronectes americanus, (Buckley, 1982); striped bass Morone saxatilis, and summer flounder Paralichthys dentatus (Buckley, unpubl.). A correlation between RNA-DNA ratio and growth rate is expected since RNA comprises a large part of the cell's protein synthesizing machinery and DNA is an index of cell number. Growth in fish as in most other oganisms is accomplished by protein synthesis. Larval fish respond to favorable growth conditions by increasing RNA content relative to DNA (Buckley, 1979). That is, the protein synthetic machinery per cell is increased. Similar relationships between RNA-DNA ratio (or RNA concentration) and growth rate have been observed for a wide variety of organisms (Leick, 1968; Bulow, 1970; Sutcliffe, 1970). As observed for winter flounder (Buckley, 1982), the relation between RNA-DNA ratio and growth rate for sand lance was improved by adding temperature as a second independent variable (Table 6, Equation 5).

The results of this study suggest that estimation of RNA-DNA ratio and water temperature are sufficient to estimate growth or condition of larval sand lance since addition of other variables including larval size or age removed very little of the unexplained variation in growth rate. The RNA-DNA ratio, temperature, and growth rate relation for sand lance (Table 6, Equation $5)$ is very similar to a general model for the relation derived from data on the larvae of seven temperate marine fish species including sand lance (Buckley, submitted). Agreement between growth estimates based on the relation between RNA-DNA ratio, temperature, and growth of sand lance and the general model is particularly good at intermediate temperatures $\left(5\right.$ to $\left.9^{\circ} \mathrm{C}\right)$. Growth estimates based on the relation between RNA-DNA ratio, temperature and growth of sand lance (Table 6, Equation 5) are slightly higher at low temperatures and lower at high temperatures than estimates based on the general model. This is due to the lower temperature coefficient in the sand lance relation suggesting an acclimation to low temperatures in sand lance larvae.

In the individual experiments, temperature and the interaction of temperature and feeding level had an effect on larval RNA-DNA ratio in only 2 out of 5 and 3 out of 5 trials, respectively (Table 4). This is in contrast to feeding level alone, which had an effect on RNADNA ratio in all 5 trials and consistently had much higher $F$ values. The effect of feeding level on larval growth and biochemical composition was generally greater than the effect of either temperature alone or the interaction of temperature and feeding level. In the combined data matrix no correlation was observed between temperature and RNA-DNA ratio of larval sand lance (Table 5). In an earlier study (Buckley, 1982), a weak correlation was observed between rearing temperature and RNA-DNA ratio of winter flounder. What little effect temperature has on larval RNADNA ratio may be indirect, acting through alteration of metabolic rate, and therefore, food requirements. This and other studies with larval fish (Buckley, 1979, 1980, 1982) have clearly demonstrated a role for supply of RNA in acclimation to various feeding levels and a role of temperature in controlling growth rate. Temperature, however, does not appear to be acting through adjustments in the supply of RNA. These observations are in agreement with the lack of evidence for a role of the supply of either messenger RNA or ribosomal RNA in temperature acclimation in poikilothermic organisms (Haschemeyer, 1978). Additional work on the biochemistry of fishes is necessary before truly useful quantitative correlations can be made between all the parameters presented in Table 4, however, the present study demonstrates which parameters are tightly coupled and which are independent. It also provides further evidence for the utility of RNA-DNA ratio measurements for estimation of growth and feeding history of larval fish.

Growth and enhanced survival above starved groups was observed even at the lowest feeding level employed $\left(0.16 \mathrm{cal} \mathrm{l}^{-1}\right)$. The beneficial effect of even low plankton densities is reflected in the RNA-DNA ratio which increased with feeding level (Table 3 ). Although Experiments I and III were not of sufficient duration to estimate mortality rates at the various prey densities, they do demonstrate the ability of young sand lance larvae to survive starvation for up to $2 \mathrm{wk}$. Using $102 \mathrm{~d}$ as the length of the larval period (Smigielski et al., 1983) and the mean mortality coefficients from Experiment II (Table 2) survival to metamorphosis is estimated at $0.12 \%, 5.75 \%$ and $11.74 \%$ at 200,500 and 1,000 rotifers $l^{-1}$, or $0.16,0.40$, and $0.80 \mathrm{cal} \mathrm{l}^{-1}$. Slower growth at the lower plankton densities would probably extend the length of the 
larval stage resulting in lower than estimated survival to metamorphosis. Survival rates of sand lance larvae at the various food levels are comparable to those of haddock Melanogrammus aeglefinus (Laurence, 1974); winter flounder Pseudopleuronectes americanus (Laurence, 1977); and northern anchovy Engraulis mordax (O'Connell and Raymond, 1970) when compared on a density basis (prey organisms ${ }^{-1}$ ) and similar to that of the bay anchovy Anchoa mitchilli (Houde, 1978) when compared on a caloric basis (calories $\mathrm{1}^{-1}$ ). The rotifers used as food in this study contain about $1 / 5$ to $1 / 8$ the calories per individual of copepod nauplii and copepodites used in the other studies. Since it is the caloric intake that is critical, sand lance larvae appear better adapted for survival at low plankton densities than cod, haddock, winter flounder or northern anchovy.

Whether or not the relatively slow growth rates observed at the lower plankton densities (Table 3) are sufficient for survival to metamorphosis at sea is open to question. Studies of the RNA-DNA ratio values of sand lance larvae collected at sea (Buckley, subritted) suggest that successful larvae grow at a faster rate at sea than observed in the laboratory. Three possible explanations for this observation are: (1) higher levels of available food at sea, (2) failure in the laboratory to meet other physiological needs of the organism such as food quality, and (3) increased selection at sea for faster growing larvae.

Growth in dry weight of sand larvae fed ad libitum a mixed diet of rotifers, brine shrimp nauplii and wild plankton consisting primarily of copepod nauplii and adults ranged from $2.4 \% \mathrm{~d}^{-1}$ at $2{ }^{\circ} \mathrm{C}$ to $5.6 \% \mathrm{~d}^{-1}$ at $10^{\circ} \mathrm{C}$ (Smigielski et al., 1983). Growth of sand lance larvae was generally similar to or slower than observed for cod, haddock, or winter flounder larvae reared under similar conditions at temperatures between 4 and $10^{\circ} \mathrm{C}$ (Laurence, 1975, 1978; Buckley, 1979). The growth differential between sand lance and those other species is greatest at the high end of the temperature range. Sand lance may have gained the capability as larvae for survival and growth at low temperatures at the expense of the potential for rapid larval growth at higher temperatures.

Several early life history characteristics of sand lance coupled with their high fecundity and short generation time may contribute to their apparent opportunism and recent success in heavily fished areas. Sand lance spawn near the end of their second year of life. Late fall-early winter spawning is unusual in the Northwest Atlantic but not unique to sand lance. Sand lance eggs are demersal, the embryonic stage long, and hatching extremely protracted (Smigielski et al., 1983). The newly hatched larva is large, very well developed, and carries an ample supply of endogenous energy reserves in the form of both oil and yolk. The larvae initiate feeding 1 to $2 \mathrm{~d}$ after hatching, well before yolk or oil is exhausted. Mortality Iate at low plankton densities in the absence of predation is low compared to other temperate species such as cod or haddock. Embryos develop and larvae grow and survive for extended periods of time at temperatures at least as low as $2^{\circ} \mathrm{C}$. Although not fully tested, larval sand lance may be capable of surviving periods of starvation in excess of $2 \mathrm{wk}$. Sand lance are welladapted for spawning during the winter minimum in zooplankton abundance. Larval sand lance that survive through the winter can take advantage of the spring maximum in zooplankton abundance (Sherman et al., in prep.) and increasing temperatures which favor rapid growth as juveniles.

\section{LITERATURE CITED}

Andersen, K. P., Ursin, E. (1978). A multispecies extension to the Beverton and Holt theory of fishing with accounts of phosphorus circulation and primary production. Rapp. P.-v. Reun. Cons. perm. int. Explor. Mer 172: 286-291

Buckley, L. J. (1979). Relationships between RNA-DNA ratio, prey density, and growth rate in Atlantic cod (Gadus morhua) larvae. J. Fish. Res. Bd Can. 36: 1497-1502

Buckley, L. J. (1980). Changes in ribonucleic acid, deoxyribonucleic acid, and protein content during ontogenesis in winter flounder, Pseudopleuronectes americanus, and the effect of starvation. Fish. Bull. U. S. 77: 703-708

Buckley, L. J. (1982). Effects of temperature on growth and biochemical composition of larval winter flounder, Pseudopleuronectes americanus. Mar Ecol. Prog. Ser 8: 181-186

Buckley, L. J. (submitted). RNA-DNA ratio: an index of larval fish growth in the sea. Mar. Biol.

Bulow, F. J. (1970). RNA-DNA ratios as indicators of recent growth rates of a fish. J. Fish. Res. Bd Can. 27: 2343-2349

Haschemeyer, A. E. V. (1978). Protein metabolism and its role in temperature acclimation. In: Malins, D. C., Sargent, J. R. (ed.) Biochemical and biophysical perspectives in marine biology, Vol. 4. Academic Press, London, p. 29-84

Houde, E. D. (1978). Critical food concentrations for larvae of three species of subtropical marine fishes. Bull. mar Sci. 28: $395-411$

Laurence, G. C. (1974). Growth and survival of haddock (Melanogrammus aeglefinus) larvae in relation to planktonic prey concentration. J. Fish. Res. Bd Can. 31: $1415-1419$

Laurence, G. C. (1975). Laboratory growth and metabolism of winter flounder, Pseudopleuronectes americanus, from hatching through metamorphosis at three temperatures. Mar Biol. 32: 223-229

Laurence, G. C. (1977). A bioenergetic model for the analysis of feeding and survival potential of winter flounder, Pseudopleuronectes americanus, larvae during the period from hatching to metamorphosis. Fish. Bull. U.S. 75: $529-546$

Laurence, G. C. (1978). Comparative growth, respiration, and delayed feeding abilities of larval cod (Gadus morhua) 
and haddock Melanogrammus aeglefinus) as influenced by temperature during laboratory studies. Mar. Biol. $50: 1-7$

Leick, V. (1968). Ratios between contents of DNA, RNA and protein in different micro-organisms as a function of maximal growth rate. Nature, Lond. 217: 1153-1155

O'Connell, C. P., Raymond, L. P. (1970). The effect of food availability on survival and growth of early post yolk-sac larvae of the northern anchovy (Engraulis mordax Girard) in the laboratory. J. exp. mar. Biol. Ecol. 5: 187-197

Sherman, K. (1980). MARMAP, a fisheries ecosystem study in the NW Atlantic: fluctuations in ichthyoplankton-zooplankton components and their potential for impact on the system. In: Diemer, F. P., Vernberg, F. J., Mirkes, D. Z. (ed.) Advanced concepts in ocean measurements for marine biology. Belle $W$. Baruch Institute for Marine Biology and Coastal Research, University of South Carolina Press, p. 9-37

Sherman, K., Jones, C., Sullivan, L., Smith, W., Berrien, P., Ejsymont, L. (1981). Congruent shifts in sand eel abun- dance in western and eastern North Atlanic ecosystems. Nature, Lond. 291: 486-489

Sherman, K., Smith, W., Morse, W., Ejsymont, L. (in prep.). Spawning strategies of fishes in relation to circulation, phytoplankton production, and pulses in zooplankton off the Northwestern United States.

Smigielski, A. S., Halavik, T. A., Buckley, L. J., Drew, S. M., Laurence, G. C. (1983). Spawning, embryo development and growth of the American sand lance Ammodytes americanus in the laboratory. Mar. Ecol. Prog. Ser. 14: $287-292$

Sutcliffe, W. H., Jr (1970). Relationship between growth rate and ribonucleic acid concentration in some invertebrates. J. Fish. Res. Bd Can. 27: 606-609

Theilacker, G. H., McMaster, M. F. (1971). Mass culture of the rotifer, Brachionas plicatilis, and its evaluation as a food for larval anchovies. Mar. Biol. 10: 183-188

Ursin, E. (1977). Multispecies fish stock assessment for the North Sea 1960-1979. Cons. int. Explor. Mer, C. M. $1977 /$ F: 42

This paper was presented by Dr. K. Sherman; it was accepted for printing on September 12, 1983 